\title{
Psychological Impact of COVID-19 on Emergency Medicine Trainee Residents in Saudi Arabia: A Cross-Sectional Quantitative Study
}

Ahmad Khobrani ( $\sim$ alkhobrani@hotmail.com )

Department of Emergency, King Abdullah bin Abdulaziz University Hospital, Princess Nourah bint Abdurhman university

Osama Kentab

Department of Emergency, King Abdullah bin Abdulaziz University Hospital, Princess Nourah bint Abdurhman university Ahmad AAl Ibrahim

Department of Emergency, King Abdullah bin Abdulaziz University Hospital, Princess Nourah bint Abdurhman university Gamil Abdellatif

Department of Emergency, King Abdullah bin Abdulaziz University Hospital, Princess Nourah bint Abdurhman university Ahmed Mosad

Department of Emergency, King Abdullah bin Abdulaziz University Hospital, Princess Nourah bint Abdurhman university

Guiria Ibrahim

Department of Emergency, King Abdullah bin Abdulaziz University Hospital, Princess Nourah bint Abdurhman university Muna Aljahany

Department of Clinical Sciences, College of Medicine, Princess Nourah Bint Abdulrahman University

\section{Research Article}

Keywords: Emergency medicine, trainee residents, COVID-19 pandemic

Posted Date: December 17th, 2021

DOI: https://doi.org/10.21203/rs.3.rs-1132318/v1

License: (9) This work is licensed under a Creative Commons Attribution 4.0 International License. Read Full License 


\section{Abstract}

Background: Psychological stress has been high among healthcare workers on the frontlines fighting coronavirus disease 2019 (COVID-19). Emergency medicine (EM) residents are members of the frontline care teams in the fight against COVID-19, which puts them at a higher risk of psychological stress compared to other medical trainees. This study examined the psychological impact of this pandemic on EM trainee residents in Saudi Arabia.

Methods: This cross-sectional quantitative study used a survey sent to EM trainee residents throughout Saudi Arabia. The questionnaire collected demographic data and included questions evaluating stress, anxiety, depression, and burnout experienced while working during the pandemic.

Results: Of the 100 respondents eligible for inclusion, 85\% were aged between 25 and 30, 32\% were in the R1 training level, $52 \%$ were training in the Central region of Saudi Arabia, 92\% were directly managing patients with COVID-19, $19 \%$ had been infected with COVID-19, 54\% were satisfied with the personal protective equipment available, $52 \%$ were satisfied with the psychological support provided, and only $8 \%$ were aware of the psychological support program. Smokers ( $p$-value $=0.025)$ and those training in the Southern region ( $p$-value $=0.047)$ experienced the highest levels of anxiety. Those aged 31 to 35 ( $p$-value $=0.014)$, smokers $(p$-value $=0.015)$, those in the R3 training level $(p$-value $=0.036)$, and those with relatives who had contracted COVID-19 $(p$-value $=0.02)$ reported the highest levels of depression. Those aged 36 to 40 ( $p$-value $=0.015)$, who were married ( $p$-value $=0.038)$, and those training in the Northern and Central regions ( $p$-value $=0.002)$ experienced the highest levels of stress. Those aged 31 to 35 ( $p$-value $=0.041)$, smokers ( $p$-value $=0.044)$, and those with relatives who had contracted COVID-19 $(p$-value $=0.043)$ showed the highest levels of burnout.

Conclusions: EM trainee residents have been exposed to significantly high psychological affectation during the COVID-19 pandemic. Psychological support was underutilized if trainee residents were aware of it at all. Awareness workshops or on-the-job orientation for EM residents regarding psychological support is required.

\section{Background}

Coronavirus disease 2019 (COVID-19) is a novel coronavirus that was first identified at the end of 2019 in Wuhan city, China. ${ }^{1}$ The virus spread rapidly throughout the Chinese population and then to other countries in the world, until a pandemic was ultimately declared in February 2020 by the World Health Organization. ${ }^{2}$ Since then, the virus has spread worldwide, with an increasing number of daily cases and deaths. ${ }^{3}$

Due to the rapid and high transmission rate of COVID-19, governments across the world became concerned about overburdening their healthcare systems with an increasing number of patients, which could lead to patients being unable to receive proper treatment and a collapse in the healthcare systems in even the most developed countries. ${ }^{4,5}$

From a clinician's perspective, the collapse of a healthcare system can occur quickly due to the pressures imposed on the healthcare team. ${ }^{6}$ These pressures include long working hours and caring for hundreds of patients in each hospital, as well as the psychological stress and anxiety suffered by clinicians due to the pandemic situation. ${ }^{7}$

These psychological stressors may be related to various factors. ${ }^{8}$ Clinicians may become stressed due to witnessing their colleagues becoming infected with COVID-19 and dying as a result of transmission of the virus from their patients. ${ }^{9}$ They may also fear getting infected themselves or transmitting the virus to their families. ${ }^{10}$ Another important source of psychological stress could be the impact of the pandemic on the career progress and training of clinicians. This is particularly important in young residents. ${ }^{11}$

Psychological stress has been high among healthcare workers on the frontlines fighting COVID-19. ${ }^{12}$ EM specialists, and particularly EM residents, are members of the frontline care teams in the fight against COVID-19, which puts them at a notably higher risk of psychological stress compared to other medical specialists. ${ }^{13}$

Therefore, this study aimed to investigate the psychological impact of the COVID-19 pandemic on EM residents enrolled in a training program in Saudi Arabia 


\section{Methods}

\section{Study design}

This is a cross-sectional, quantitative survey-based study. A pre-designated validated SurveyMonkey questionnaire was used to assess the psychological wellbeing of Saudi Board of EM trainees during the COVID-19 pandemic to identify the impact of COVID19 on their training using the Generalized Anxiety Disorder Scale, Perceived Stress Scale, Zung Self-Rating Depression Scale (SDS), and Oldenburg Burnout Inventory. ${ }^{14-17}$ All of the questions in the questionnaire were validated.

Participation in the study was entirely voluntary, and all the participants provided their written consent to participate before completing the survey. The study protocol was approved by the Institutional Review Board of the Princess Nourah bint Abdulrahman University (IRB log number: 20-0269).

The questionnaire included seven domains:

1. Sociodemographic data (10 items): including age, gender, specialty, place of residence, training region, level of residency, marital status, treating COVID-19 patients, previous infection with COVID-19, family members infected with COVID-19.

2. Exclusion criteria (4 items): including questions about pre-existing mental illnesses, not working during the COVID-19 pandemic, and lockdown.

3. Anxiety assessment. according to the Generalized Anxiety Disorder Scale using a validated questionnaire (7 items).

4. Depression assessment. according to the SDS using a validated questionnaire (20 items).

5. Stress assessment. according to the Perceived Stress Scale using a validated questionnaire (10 items).

6. Burnout assessment. according to Oldenburg Burnout Inventory using a validated questionnaire (16 items).

7. Satisfaction with the psychological support program (DAEM): received from the training hospital and the Saudi Commission of Health Specialties (SCHS).

\section{Study setting}

The study was conducted by the authors who are practicing at the King Abdullah Bin Abdulaziz University Hospital, Saudi Arabia. The program directors of all EM residency programs across the Kingdom that fall under the SCHS were contacted via email and were asked to send all residents the Survey Monkey link.

\section{Eligibility criteria}

All trainee residents in Saudi Board Emergency Programs under the SCHS were eligible for inclusion. However, service residents not enrolled in the Saudi Board Emergency Program, trainee residents diagnosed with mental illness, and trainee residents who were not working during the COVID-19 pandemic were excluded.

\section{Statistical analysis}

The internal consistency of the whole questionnaire and the specific items related to the psychological impact of COVID-19 were tested using a Cronbach's alpha test to validate it. The descriptive analysis included frequencies and percentages of all categorical variables. Items related to the psychological impact domains were analyzed using one-way ANOVA testing with a significance $p$ value of $<0.05$. Statistical analysis was performed using the Statistical Package for Social Sciences version 26.0 (SPSS Inc., Chicago, IL, USA).

\section{Results}

A total of 139 residents responded to the questionnaire, 100 of whom were EM trainee residents. Respondents who did not work during the COVID-19 pandemic and those who were on service jobs were excluded $(\mathrm{N}=39)$. The description of the included cohort is 
discussed below.

\section{Demographic information}

As shown in Table 1, age was subcategorized into three groups and $85 \%$ of the respondents were aged between 25 and 30 years old. Of the included cohort, $67 \%$ were males, $62 \%$ were single, and $41 \%$ were living with their parents. Regarding training level, $32 \%$ were in the R1 training level, and $52 \%$ were being trained in the Central region of Saudi Arabia.

Table 1 Respondents' demographic data

\begin{tabular}{|c|c|c|c|}
\hline & & Count $(\mathrm{N}=100)$ & Percent (\%) \\
\hline \multirow[t]{3}{*}{ Age group } & $25-30$ & 85 & 85.0 \\
\hline & $31-35$ & 12 & 12.0 \\
\hline & $36-40$ & 3 & 3.0 \\
\hline \multirow[t]{2}{*}{ Gender } & Male & 67 & 67.0 \\
\hline & Female & 33 & 33.0 \\
\hline \multirow[t]{3}{*}{ Marital status } & Single & 62 & 62.0 \\
\hline & Married & 33 & 33.0 \\
\hline & Separated & 5 & 5.0 \\
\hline \multirow[t]{4}{*}{ Living with } & Parent/s & 41 & 41.0 \\
\hline & Spouse and children & 27 & 27.0 \\
\hline & Alone & 25 & 25.0 \\
\hline & Friend & 7 & 7.0 \\
\hline \multirow[t]{4}{*}{ Training level } & $\mathrm{R} 1$ & 32 & 32.0 \\
\hline & $\mathrm{R} 2$ & 29 & 29.0 \\
\hline & R3 & 24 & 24.0 \\
\hline & $\mathrm{R} 4$ & 15 & 15.0 \\
\hline \multirow[t]{5}{*}{ Training region } & Central region & 52 & 52.0 \\
\hline & West region & 27 & 27.0 \\
\hline & East region & 15 & 15.0 \\
\hline & South region & 5 & 5.0 \\
\hline & North region & 1 & 1.0 \\
\hline
\end{tabular}

\section{Working during the COVID-19 pandemic}

As shown in Table 2, all of the respondents worked during the COVID-19 pandemic and $92 \%$ of them were directly managing patients with COVID-19. A total of $19 \%$ of the respondents were infected with COVID-19 and $26 \%$ had family members who were infected.

Table 2 Working during the COVID-19 pandemic

\begin{tabular}{lllll}
\hline & \multicolumn{3}{r}{ Count (N=100) } & Percent (\%) \\
\hline Managing patients with COVID-19 & Yes & 92 & 92.0 \\
\cline { 2 - 4 } & No & 8 & 8.0 \\
\hline Being infected with COVID-19 & Yes & 19 & 19.0 \\
\cline { 2 - 4 } & No & 81 & 81.0 \\
\hline Family members infected with COVID-19 & Yes & 26 & 26.0 \\
\cline { 2 - 4 } & No & 74 & 74.0 \\
\hline
\end{tabular}




\section{Medical and social history}

Of the included cohort, $48 \%$ were smokers, while $18 \%$ had a chronic medical condition. The most common medical condition was a chronic respiratory disease, occurring in $6 \%$ of respondents. Additionally, $14 \%$ had a psychiatric illness (Table 3 ).

Table 3 Medical and social history

\begin{tabular}{|c|c|c|c|}
\hline & & Count & Percent \\
\hline \multirow[t]{2}{*}{ Smoking } & Yes & 48 & 48.0 \\
\hline & No & 52 & 52.0 \\
\hline \multirow[t]{10}{*}{ Medical illness } & No & 82 & 82.0 \\
\hline & Chronic respiratory disease & 6 & 6.0 \\
\hline & Thyroid disorder & 3 & 3.0 \\
\hline & Hypertension & 3 & 3.0 \\
\hline & Diabetes mellitus & 2 & 2.0 \\
\hline & Migraine & 2 & 2.0 \\
\hline & Chronic urticaria & 1 & 1.0 \\
\hline & Fatty liver & 1 & 1.0 \\
\hline & GERD due to paraoesophageal hiatus hernia & 1 & 1.0 \\
\hline & Syringomyelia & 1 & 1.0 \\
\hline \multirow[t]{4}{*}{ Psychiatric illness } & No & 86 & 86.0 \\
\hline & Depression & 5 & 5.0 \\
\hline & Generalized anxiety disorder & 6 & 6.0 \\
\hline & Other & 3 & 3.0 \\
\hline
\end{tabular}

\section{Anxiety assessment}

A shown in Table 4, respondents were asked a set of questions to evaluate their anxiety levels during the pandemic. They could choose between five responses, each of which was scored based on the severity of anxiety (for example, not at all = zero points, nearly every day $=3$ points).

Table 4 Anxiety assessment

\begin{tabular}{|c|c|c|c|c|c|}
\hline & $\begin{array}{l}\text { Not at } \\
\text { all }\end{array}$ & $\begin{array}{l}\text { Several } \\
\text { days }\end{array}$ & $\begin{array}{l}\text { More than half of the } \\
\text { days }\end{array}$ & $\begin{array}{l}\text { Nearly every } \\
\text { day }\end{array}$ & $\begin{array}{l}\text { Cronbach's } \\
\text { alpha }\end{array}$ \\
\hline Feeling nervous, anxious, or on edge & 13 & 42 & 30 & 15 & 0.863 \\
\hline Not being able to stop or control worrying & 25 & 45 & 18 & 12 & 0.863 \\
\hline Worrying too much about different things & 19 & 32 & 27 & 22 & 0.862 \\
\hline Trouble relaxing & 21 & 33 & 28 & 18 & 0.863 \\
\hline Being so restless that it's hard to sit still & 38 & 37 & 20 & 5 & 0.863 \\
\hline Becoming easily annoyed or irritable & 23 & 41 & 24 & 12 & 0.863 \\
\hline $\begin{array}{l}\text { Feeling afraid as if something awful might } \\
\text { happen }\end{array}$ & 25 & 45 & 18 & 15 & 0.863 \\
\hline
\end{tabular}


To evaluate the validity of the questions, Cronbach's alpha was calculated for the questions and was above 0.7 for all of them, which demonstrates the validity of the items.

Over a third of the respondents mentioned that they were feeling nervous, were unable to control their worrying, had trouble relaxing, worried too much, felt restless and irritable, and felt afraid for several days.

Additionally, respondents were asked about the level of difficulty caused by their anxiety while performing daily tasks both at work and at home. More than half of the respondents found that it was somewhat difficult.

\section{Depression assessment}

A validated version of the SDS was used to evaluate the respondents' depression levels. The validity of the questions was tested using Cronbach's alpha and showed levels above 0.7 . The respondents had to choose from four options and their responses were scored according to how much of the time they felt depressed (a little of the time $=1$, most of the time $=4$ ).

As shown in Table 5, more than one-third of the respondents showed significant depression manifestations for a little of the time during the pandemic. Less than one-quarter of the respondents reported feeling that they are useful, finding their lives pretty full, and enjoying things they used to do a little of the time.

Table 5 Depression assessment

\begin{tabular}{|c|c|c|c|c|c|}
\hline & $\begin{array}{l}\text { A little of the } \\
\text { time }\end{array}$ & $\begin{array}{l}\text { Some of the } \\
\text { time }\end{array}$ & $\begin{array}{l}\text { Good part of the } \\
\text { time }\end{array}$ & $\begin{array}{l}\text { Most of the } \\
\text { time }\end{array}$ & $\begin{array}{l}\text { Cronbach's } \\
\text { alpha }\end{array}$ \\
\hline I feel down-hearted and blue & 44 & 28 & 23 & 5 & 0.964 \\
\hline Morning is when I feel the best & 41 & 27 & 15 & 17 & 0.964 \\
\hline I have crying spells or feel like crying & 61 & 22 & 14 & 3 & 0.964 \\
\hline I have trouble sleeping at night & 39 & 28 & 18 & 15 & 0.964 \\
\hline I eat as much as I used to & 34 & 21 & 16 & 29 & 0.964 \\
\hline I still enjoy sex & 49 & 19 & 16 & 16 & 0.964 \\
\hline I notice that I am losing weight & 72 & 16 & 6 & 6 & 0.964 \\
\hline I have trouble with constipation & 63 & 20 & 12 & 5 & 0.964 \\
\hline I get tired for no reason & 34 & 22 & 23 & 21 & 0.964 \\
\hline My mind is as clear as it used to be & 53 & 28 & 9 & 10 & 0.968 \\
\hline I find it easy to do the things I used to & 43 & 32 & 13 & 12 & 0.964 \\
\hline I am restless and can't keep still & 59 & 19 & 19 & 3 & 0.964 \\
\hline I feel hopeful about the future & 32 & 27 & 29 & 12 & 0.964 \\
\hline I am more irritable than usual & 39 & 24 & 28 & 9 & 0.964 \\
\hline I find it easy to make decisions & 26 & 35 & 32 & 7 & 0.968 \\
\hline I feel that I am useful and needed & 25 & 28 & 26 & 21 & 0.964 \\
\hline My life is pretty full & 22 & 35 & 23 & 20 & 0.964 \\
\hline $\begin{array}{l}\text { I feel that others would be better off if I were } \\
\text { dead }\end{array}$ & 80 & 11 & 5 & 4 & 0.964 \\
\hline I still enjoy the things I used to do & 23 & 43 & 18 & 16 & 0.964 \\
\hline
\end{tabular}


The respondents' stress was evaluated using a set of 10 questions, which were validated using Cronbach's alpha, which showed values above 0.7 for all questions. The respondents had to choose from five responses (never $=0$, very often $=4$ ).

More than half of the respondents were sometimes unable to control irritations, felt that they were on top of things, were angered because of things out of their control, and felt difficulties were piling up so high that they could not overcome them, as shown in Table 6.

Table 6 Perceived stress scale

\begin{tabular}{|c|c|c|c|c|c|c|}
\hline & Never & $\begin{array}{l}\text { Almost } \\
\text { never }\end{array}$ & Sometimes & $\begin{array}{l}\text { Fairly } \\
\text { often }\end{array}$ & $\begin{array}{l}\text { Very } \\
\text { often }\end{array}$ & $\begin{array}{l}\text { Cronbach's } \\
\text { alpha }\end{array}$ \\
\hline $\begin{array}{l}\text { How often have you been upset because of something that happened } \\
\text { unexpectedly? }\end{array}$ & 2 & 8 & 35 & 45 & 10 & 0.847 \\
\hline $\begin{array}{l}\text { How often have you felt that you were unable to control the important } \\
\text { things in your life? }\end{array}$ & 5 & 11 & 37 & 41 & 6 & 0.847 \\
\hline How often have you felt nervous and stressed? & 2 & 7 & 27 & 50 & 14 & 0.847 \\
\hline $\begin{array}{l}\text { How often have you felt confident about your ability to handle your } \\
\text { personal problems? }\end{array}$ & 2 & 5 & 31 & 48 & 14 & 0.847 \\
\hline How often have you felt that things were going your way? & 1 & 9 & 35 & 50 & 5 & 0.847 \\
\hline $\begin{array}{l}\text { How often have you found that you could not cope with all the things that } \\
\text { you had to do? }\end{array}$ & 6 & 10 & 31 & 41 & 12 & 0.847 \\
\hline How often have you been able to control irritations in your life? & 2 & 2 & 68 & 21 & 7 & 0.847 \\
\hline How often have you felt that you were on top of things? & 2 & 9 & 67 & 18 & 4 & 0.847 \\
\hline $\begin{array}{l}\text { How often have you been angered because of things that were outside } \\
\text { your control? }\end{array}$ & 4 & 9 & 57 & 22 & 8 & 0.847 \\
\hline $\begin{array}{l}\text { How often have you felt difficulties were piling up so high that you could } \\
\text { not overcome them? }\end{array}$ & 1 & 15 & 66 & 10 & 8 & 0.847 \\
\hline
\end{tabular}

\section{Burnout evaluation}

Burnout was evaluated by a set of 16 questions validated by Cronbach's alpha showing levels greater than 0.7 for all questions. Respondents were asked to choose between strongly agree $=1$ and strongly disagree $=4$. More than half of the respondents agreed on all of the questions demonstrating high levels of burnout, as shown in Table 7.

Table 7 Burnout assessment 


\begin{tabular}{|c|c|c|c|c|c|}
\hline & $\begin{array}{l}\text { Strongly } \\
\text { agree }\end{array}$ & Agree & Disagree & $\begin{array}{l}\text { Strongly } \\
\text { disagree }\end{array}$ & $\begin{array}{l}\text { Cronbach's } \\
\text { alpha }\end{array}$ \\
\hline I always find new and interesting aspects of my work & 8 & 72 & 12 & 8 & 0.899 \\
\hline There are days when I feel tired before I arrive at work & 17 & 65 & 13 & 5 & 0.899 \\
\hline $\begin{array}{l}\text { It happens more and more often that I talk about my work in a negative } \\
\text { way }\end{array}$ & 9 & 60 & 22 & 9 & 0.899 \\
\hline $\begin{array}{l}\text { After work, I tend to need more time than in the past in order to relax } \\
\text { and feel better }\end{array}$ & 16 & 66 & 12 & 6 & 0.899 \\
\hline I can tolerate the pressure of my work very well & 9 & 68 & 18 & 5 & 0.899 \\
\hline Lately, I tend to think less at work and do any job almost mechanically & 8 & 62 & 25 & 5 & 0.899 \\
\hline I find my work to be a positive challenge & 13 & 72 & 9 & 6 & 0.899 \\
\hline During my work, I often feel emotionally drained & 14 & 60 & 19 & 7 & 0.899 \\
\hline Over time, one can become disconnected from this type of work & 6 & 63 & 27 & 4 & 0.899 \\
\hline After working, I have enough energy for my leisure activities & 4 & 53 & 27 & 16 & 0.899 \\
\hline Sometimes I feel sickened by my work tasks & 5 & 72 & 17 & 6 & 0.896 \\
\hline After my work, I usually feel worn out and weary & 13 & 67 & 17 & 3 & 0.899 \\
\hline This is the only type of work that I can imagine myself doing & 22 & 57 & 11 & 10 & 0.899 \\
\hline Usually, I can manage my amount of work well & 13 & 74 & 5 & 8 & 0.899 \\
\hline I feel more and more engaged in my work & 11 & 71 & 13 & 5 & 0.896 \\
\hline When I work, I usually feel energized & 9 & 70 & 16 & 5 & 0.899 \\
\hline
\end{tabular}

\section{Total psychological stress score}

Finally, each section's total scores were calculated and a total score was calculated for the four sections together as a total psychological stress score. Mean, SD, minimum, and maximum scores are detailed in Table 8.

Table 8 Mean scores for each section (in points)

\begin{tabular}{lllll}
\hline & Mean & SD & Minimum & Maximum \\
\hline Anxiety assessment score & 16.2 & 1.6 & 0 & 21 \\
\hline Depression (SDS) & 53.1 & 2.8 & 0 & 80 \\
\hline Perceived stress scale & 32.6 & 1.8 & 0 & 40 \\
\hline Burnout & 51.3 & 2.6 & 0 & 64 \\
\hline Total psychological stress score & 173.2 & 5.8 & 0 & 205 \\
\hline
\end{tabular}

\section{The satisfaction of respondents with the psychological support provided}

As shown in Table 9, $54 \%$ of the respondents were satisfied with the personal protective equipment available, $52 \%$ were satisfied with the psychological support provided, and only $8 \%$ were aware of the DAEM offered by the SCHS for the training of healthcare workers.

Table 9 Satisfaction of respondents 


\begin{tabular}{|c|c|c|c|}
\hline & & Count & Percent \\
\hline \multirow[t]{2}{*}{ Satisfied with PPE availability in your hospital? } & Yes & 54 & 54.0 \\
\hline & No & 46 & 46.0 \\
\hline \multirow[t]{2}{*}{ Satisfied with the psychological support provided to you by your training hospital? } & Yes & 52 & 52.0 \\
\hline & No & 48 & 48.0 \\
\hline \multirow{3}{*}{$\begin{array}{l}\text { Are you aware of the psychological support program (DAEM) offered by the SCHS for } \\
\text { trainee healthcare workers? }\end{array}$} & Yes, I already use it & 8 & 8.0 \\
\hline & $\begin{array}{l}\text { I don't know about this } \\
\text { program }\end{array}$ & 38 & 38.0 \\
\hline & No, I did not try it & 54 & 54.0 \\
\hline
\end{tabular}

Furthermore, respondent's satisfaction was evaluated across the different regions. The highest satisfaction rates with PPE was demonstrated in the East region (73.\%), the highest satisfaction with the psychological support was in the South region (80\%), while only $9.6 \%$ in the Central region and $11.1 \%$ in the West region knew about the DAEM and used it, as shown in Table 10.

Table 10 Satisfaction of residents in each region 


\begin{tabular}{|c|c|c|c|c|}
\hline & Region & & Count & Percent \\
\hline \multirow[t]{10}{*}{ Satisfied with PPE availability in your hospital? } & Central & & 33 & 63.5 \\
\hline & region & & & \\
\hline & East & & 11 & 73.3 \\
\hline & region & & & \\
\hline & North & & 0 & 0 \\
\hline & region & & & \\
\hline & South & & 1 & 20.0 \\
\hline & region & & & \\
\hline & West & & 9 & 33.3 \\
\hline & region & & & \\
\hline \multirow[t]{10}{*}{ Satisfied with the psychological support provided to you by your training hospital? } & Central & & 27 & 51.9 \\
\hline & region & & & \\
\hline & East & & 8 & 53.3 \\
\hline & region & & & \\
\hline & North & & 0 & 0 \\
\hline & region & & & \\
\hline & South & & 4 & 80.0 \\
\hline & region & & & \\
\hline & West & & 13 & 48.1 \\
\hline & region & & & \\
\hline \multirow{12}{*}{$\begin{array}{l}\text { Are you aware of the psychological support program (DAEM) offered by the SCHS } \\
\text { for trainee healthcare workers? }\end{array}$} & Central & Yes, I have already & 5 & 9.6 \\
\hline & region & used it & & \\
\hline & & $\begin{array}{l}\text { I don't know about this } \\
\text { program }\end{array}$ & 22 & 42.3 \\
\hline & & No, I did not try it & 25 & 48.1 \\
\hline & $\begin{array}{l}\text { East } \\
\text { region }\end{array}$ & $\begin{array}{l}\text { I don't know about this } \\
\text { program }\end{array}$ & 46.7 & 46.7 \\
\hline & & No, I did not try it & 53.3 & 53.3 \\
\hline & $\begin{array}{l}\text { North } \\
\text { region }\end{array}$ & No, I did not try it & 1 & 100.0 \\
\hline & $\begin{array}{l}\text { South } \\
\text { region }\end{array}$ & $\begin{array}{l}\text { I don't know about this } \\
\text { program }\end{array}$ & 1 & 20.0 \\
\hline & & No, I did not try it & 4 & 80.0 \\
\hline & $\begin{array}{l}\text { West } \\
\text { region }\end{array}$ & $\begin{array}{l}\text { Yes, I have already } \\
\text { used it }\end{array}$ & 3 & 11.1 \\
\hline & & $\begin{array}{l}\text { I don't know about this } \\
\text { program }\end{array}$ & 8 & 29.6 \\
\hline & & No, I did not try it & 16 & 59.3 \\
\hline
\end{tabular}


To identify respondents who were the most psychologically affected during the pandemic, each section's mean score and the mean score for total psychological stress were compared across different demographic variables using one-way ANOVA at a level of significance with a p-value of $<0.05$.

Regarding anxiety levels, smokers $(p$-value $=0.025)$ and residents trained in the South region ( $p$-value $=0.047)$ suffered significantly from anxiety compared to their peers. Concerning the depression scale, respondents aged between 31 to 35 ( $p$-value $=0.014)$, smokers ( $p$-value $=0.015)$, those in the R3 training level $(p$-value $=0.036)$, and those with relatives who had COVID-19 $(p$-value $=$ 0.02 ) showed the highest levels of depression. Turning to stress, those aged between 36 to 40 ( $p$-value $=0.015$ ), who were married $(p$-value $=0.038)$, and training in the North and Central regions ( $p$-value $=0.002)$ showed the highest stress levels. Those aged 31 to 35 ( $p$-value $=0.041)$, smokers $(p$-value $=0.044)$ and those with relatives infected with COVID-19 $(p$-value $=0.043)$ showed the highest levels of burnout.

Finally, total psychological affectation was significantly higher among smokers ( $p$-value $=0.025)$, those in the R3 training level ( $p$ value $=0.046)$, and those infected with COVID-19 $(p$-value $=0.035)$ while psychological affectation was significantly lower among non-smokers (52 respondents) ( $p$-value $=0.025)$, residents in the R2 training level (29 respondents) ( $p$-value $=0.046)$, and residents who were not infected with COVID-19 (81 respondents) ( $p$-value $=0.035)$, as shown in Table 11.

Table 11 Comparison of the mean scores 


\begin{tabular}{|c|c|c|c|c|c|c|c|c|c|c|c|}
\hline & & $\begin{array}{l}\text { Anxiety } \\
\text { assessment } \\
\text { score } \\
\text { (Mean士SD) }\end{array}$ & $\begin{array}{l}\mathrm{P} \text { - } \\
\text { value }\end{array}$ & $\begin{array}{l}\text { Depression } \\
\text { scale (SDS) } \\
(\text { Mean } \pm S D)\end{array}$ & $\begin{array}{l}\mathrm{P} \text { - } \\
\text { value }\end{array}$ & $\begin{array}{l}\text { Stress } \\
\text { scale } \\
\text { (Mean士SD) }\end{array}$ & $\begin{array}{l}\mathrm{P} \text { - } \\
\text { value }\end{array}$ & $\begin{array}{l}\text { Burnout } \\
\text { (Mean } \pm \text { SD) }\end{array}$ & $\begin{array}{l}\mathrm{P} \text { - } \\
\text { value }\end{array}$ & $\begin{array}{l}\text { Total } \\
\text { psychological } \\
\text { stress score } \\
\text { (Mean } \pm \text { SD) }\end{array}$ & $\begin{array}{l}\text { P- } \\
\text { value }\end{array}$ \\
\hline \multirow{3}{*}{$\begin{array}{l}\text { Age } \\
\text { group }\end{array}$} & $25-30$ & $12 \pm 1.6$ & \multirow[t]{3}{*}{0.850} & $49 \pm 2.2$ & \multirow[t]{3}{*}{$0.014^{*}$} & $21 \pm 1.4$ & \multirow[t]{3}{*}{$0.015^{*}$} & $41 \pm 2.3$ & \multirow[t]{3}{*}{$0.041^{*}$} & $122 \pm 5.1$ & \multirow[t]{3}{*}{0.116} \\
\hline & $31-35$ & $18 \pm 2.1$ & & $64 \pm 5.1$ & & $26 \pm 3.2$ & & $52 \pm 1.8$ & & $145 \pm 9.5$ & \\
\hline & $36-40$ & $13.3 \pm 1.7$ & & $59 \pm 1.2$ & & $34 \pm 4.1$ & & $43 \pm 9.2$ & & $183 \pm 8.3$ & \\
\hline \multirow[t]{2}{*}{ Gender } & Male & $14.3 \pm 0.8$ & \multirow[t]{2}{*}{0.151} & $69 \pm 3.2$ & \multirow[t]{2}{*}{0.067} & $34.9 \pm 1.9$ & \multirow[t]{2}{*}{0.728} & $51.8 \pm 2.9$ & \multirow[t]{2}{*}{0.891} & $184 \pm 3.2$ & \multirow[t]{2}{*}{0.541} \\
\hline & Female & $19.2 \pm 2$ & & $56 \pm 1.7$ & & $30.8 \pm 1.5$ & & $47.7 \pm 2.3$ & & $164 \pm 2.3$ & \\
\hline \multirow[t]{2}{*}{ Smoking } & Yes & $18.1 \pm 1.9$ & \multirow[t]{2}{*}{$0.025^{*}$} & $64.2 \pm 3.5$ & \multirow[t]{2}{*}{$0.015^{*}$} & $32.2 \pm 2.2$ & \multirow[t]{2}{*}{0.152} & $57.2 \pm 1.4$ & \multirow[t]{2}{*}{$0.044^{*}$} & $162 \pm 2.8$ & \multirow[t]{2}{*}{$0.025^{*}$} \\
\hline & No & $13.3 \pm 1.4$ & & $52.1 \pm 1.6$ & & $27.4 \pm 1.3$ & & $49.4 \pm 2.2$ & & $143 \pm 3.9$ & \\
\hline \multirow{3}{*}{$\begin{array}{l}\text { Marital } \\
\text { status }\end{array}$} & Single & $14.3 \pm 1.5$ & \multirow[t]{3}{*}{0.170} & $51.8 \pm 2.1$ & \multirow[t]{3}{*}{0.054} & $27.3 \pm 1.2$ & \multirow[t]{3}{*}{$0.038 *$} & $58.4 \pm 2.3$ & \multirow[t]{3}{*}{0.797} & $154.1 \pm 4.6$ & \multirow[t]{3}{*}{0.084} \\
\hline & Married & $17.2 \pm 1.9$ & & $62.1 \pm 3.6$ & & $31.2 \pm 2.6$ & & $52.4 \pm 3.2$ & & $168.3 \pm 7.6$ & \\
\hline & Separated & $12.9 \pm 0.4$ & & $53.8 \pm 2.3$ & & $22.5 \pm 0.5$ & & $47.8 \pm 2.1$ & & $142.5 \pm 4.5$ & \\
\hline \multirow{4}{*}{$\begin{array}{l}\text { Living } \\
\text { with }\end{array}$} & Parent/s & $16.2 \pm 1.5$ & \multirow[t]{4}{*}{0.620} & $51.3 \pm 2.4$ & \multirow[t]{4}{*}{0.920} & $28.3 \pm 1.2$ & \multirow[t]{4}{*}{0.371} & $52.8 \pm 2.4$ & \multirow[t]{4}{*}{0.773} & $146.6 \pm$ & 0.843 \\
\hline & $\begin{array}{l}\text { Spouse } \\
\text { and } \\
\text { children }\end{array}$ & $17.2 \pm 1.7$ & & $60.4 \pm 2.3$ & & $38.4 \pm 2.3$ & & $41.8 \pm 3.5$ & & $152.9 \pm$ & \\
\hline & Alone & $12.3 \pm 1.9$ & & $54.8 \pm 3.8$ & & $32.1 \pm 2.1$ & & $59.4 \pm 2.3$ & & $162.3 \pm$ & \\
\hline & Friend & $10.2 \pm 0.5$ & & $68.8 \pm 2.9$ & & $21.3 \pm 0.3$ & & $46.9 \pm 2.3$ & & $141.3 \pm$ & \\
\hline Training & $\mathrm{R} 1$ & $15.6 \pm 1.6$ & 0.520 & $43 \pm 2.3$ & $0.036^{*}$ & $20 \pm 0.9$ & 0.627 & $48 \pm 2.2$ & 0.798 & $134 \pm 4.8$ & $0.046^{*}$ \\
\hline level & $\mathrm{R} 2$ & $18.4 \pm 1.8$ & & $51 \pm 2.0$ & & $30 \pm 1.9$ & & $39 \pm 2.3$ & & $129 \pm 5.9$ & \\
\hline & R3 & $12.2 \pm 1.6$ & & $71 \pm 4.2$ & & $34 \pm 2.5$ & & $53 \pm 3.8$ & & $178 \pm 7.8$ & \\
\hline & $\mathrm{R} 4$ & $19.3 \pm 1.5$ & & $62 \pm 2.1$ & & $27 \pm 1.8$ & & $42 \pm 2.1$ & & $157 \pm 4.2$ & \\
\hline $\begin{array}{l}\text { Training } \\
\text { region }\end{array}$ & $\begin{array}{l}\text { Central } \\
\text { region }\end{array}$ & $14.4 \pm 1.7$ & $0.047 *$ & $67 \pm 3.3$ & 0.844 & $30 \pm 2.2$ & $0.002 *$ & $53.4 \pm 3.1$ & 0.253 & $168.2 \pm 3.2$ & 0.260 \\
\hline & $\begin{array}{l}\text { East } \\
\text { region }\end{array}$ & $16.2 \pm 2.2$ & & $61 \pm 2.4$ & & $24 \pm 1.4$ & & $44.2 \pm 1.9$ & & $162.3 \pm 1.9$ & \\
\hline & $\begin{array}{l}\text { North } \\
\text { region }\end{array}$ & $13.8 \pm 1.3$ & & $50 \pm 1.6$ & & $36 \pm 2.3$ & & $36.5 \pm 2.3$ & & $175.5 \pm 2.4$ & \\
\hline & $\begin{array}{l}\text { South } \\
\text { region }\end{array}$ & $18.3 \pm 2.3$ & & $53 \pm 1.9$ & & $14 \pm 2.1$ & & $40.3 \pm 1.3$ & & $154.8 \pm 4.1$ & \\
\hline & $\begin{array}{l}\text { West } \\
\text { region }\end{array}$ & $11.1 \pm 2.1$ & & $47 \pm 2.8$ & & $21 \pm 0.7$ & & $49.2 \pm 2.1$ & & $150.7 \pm 5.8$ & \\
\hline $\begin{array}{l}\text { Managing } \\
\text { patients }\end{array}$ & Yes & $18.3 \pm 1.05$ & 0.194 & $60.2 \pm 2.3$ & 0.946 & $32.1 \pm 1.7$ & 0.546 & $52.3 \pm 2.8$ & 0.865 & $160.3 \pm 6.1$ & 0.543 \\
\hline COVID-19 & No & $12.5 \pm 0.25$ & & $64.2 \pm 2.4$ & & $24.3 \pm 1.6$ & & $46.1 \pm 2.1$ & & $142.3 \pm 4.5$ & \\
\hline $\begin{array}{l}\text { Being } \\
\text { infected }\end{array}$ & Yes & $12.6 \pm 0.8$ & 0.671 & $64.2 \pm 2.4$ & $0.02 *$ & $32.1 \pm 1.3$ & 0.201 & $55.2 \pm 2.2$ & $0.043^{*}$ & $153.8 \pm 5.2$ & $0.035 *$ \\
\hline COVID-19 & No & $16.8 \pm 1.1$ & & $62.8 \pm 2.3$ & & $27.2 \pm 0.7$ & & $49.8 \pm 1.7$ & & $148.6 \pm 6.1$ & \\
\hline $\begin{array}{l}\text { An } \\
\text { infected }\end{array}$ & Yes & $16.8 \pm 1.1$ & 0.659 & $52.3 \pm 2.1$ & 0.195 & $29.3 \pm 0.9$ & 0.914 & $53.9 \pm 2.3$ & 0.244 & $152.3 \pm 5.9$ & 0.993 \\
\hline
\end{tabular}




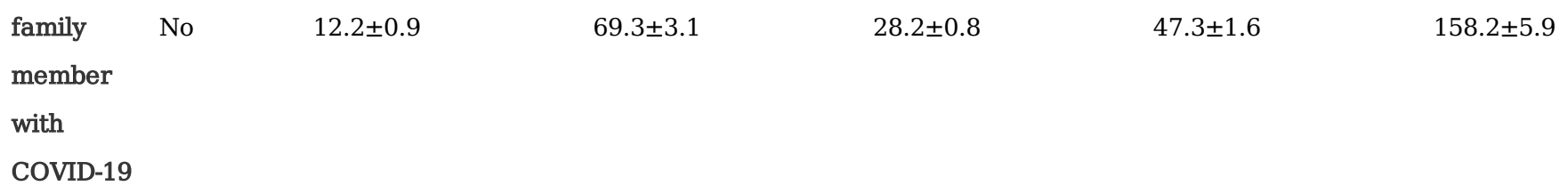

\section{Discussion}

Stress and anxiety can significantly impair the quality of life and the professional performance of healthcare professionals. ${ }^{18}$ Due to the COVID-19 pandemic, healthcare workers working on the frontline have been exposed to unprecedented stressors that could influence the healthcare service provided to their COVID-19 patients ${ }^{19}$ and elevate their risk of infection due to a reduction in their immunity caused by stress and other concerns that they might have. ${ }^{20}$

The present study aimed to evaluate the psychological impact of the COVID-19 pandemic on EM trainee residents in Saudi Arabia. It demonstrated that trainee residents are exposed to significant psychological risk due to increased stress, anxiety, burnout, and depression. It should be noted that smokers ( $p$-value $=0.025)$, residents in the R3 training level ( $p$-value $=0.046)$, and those infected with COVID-19 ( $p$-value $=0.035)$ were the most likely to be psychologically impacted by working during the pandemic.

Although the Saudi Board of EM has made DAEM available for all trainee residents, only $8 \%$ of the included cohort knew about it and used it and $38 \%$ did not know that the program existed. Levels of stress, anxiety, depression, and burnout differed among residents; however, the mean scores for the four assessments were above average, reflecting high levels of psychological affectation among all trainee residents during this exceptional situation.

The psychological impact of COVID-19 has been evaluated by different healthcare professionals. Kang et al ${ }^{21}$ demonstrated that the most prevalent type of psychological disturbance among physicians was mild anxiety which was found in $34.4 \%$ of their respondents. However, Kang et al ${ }^{21}$ also demonstrated that $50.4 \%$ of the healthcare workers in their study had access to some psychological support materials through the media, which helped to reduce their stress.

Chung et al ${ }^{22}$ compared the psychological and emotional stress that frontline physicians are exposed to with that experienced by other hospital staff. They revealed that frontline physicians suffer higher levels of emotional stress because of their fears that they will transmit COVID-19 to their families.

Similarly, the present study demonstrated high levels of anxiety, depression, burnout, and stress among emergency medicine trainee residents working during the pandemic.

Furthermore, Li et al ${ }^{23}$ assessed the psychological stress experienced by nurses working on the frontline and revealed that they had significantly lower stress compared to those working in non-frontline services ( $p$ value $<0.001$ ). This was due to the psychological training given to these nurses. ${ }^{23}$

These findings were in line with those of Huang et al, ${ }^{24}$ who found higher anxiety among nurses than doctors $(p$ value $=0.039)$. Moreover, Huang et al ${ }^{24}$ showed that females were at significantly higher risk of anxiety ( $p$ value $<0.045$ ) and that $16.09 \%$ of healthcare workers had mild anxiety, ${ }^{24}$ which was also supported by Lai et al. ${ }^{25}$

In the present study, a non-significant difference was detected between males and females in terms of anxiety, stress, burnout, depression, and total psychological impact. . Factors related to training conditions (level of training and region of training) and being infected with COVID-19, however, showed a significant difference across the different aspects that were evaluated.

Another recent systematic review by Pappa et al ${ }^{26}$ demonstrated that almost $20 \%$ of healthcare professionals suffered from anxiety and depression, which were more prevalent among females. However, Wilson et al ${ }^{2}$ described a depression prevalence of $11.4 \%$ and an anxiety prevalence of $17.7 \%$ among Indian healthcare professionals, with a higher incidence of symptoms among 
females. A review article by Salari et al ${ }^{27}$ described the incidence of anxiety as being as high as $31.9 \%$, while the incidence of depression was $33.7 \%$, among healthcare professionals.

Alamri et al ${ }^{28}$ examined the effect of the COVID-19 pandemic on health professionals in Saudi Arabia and found that $17.1 \%$ had depression, $10 \%$ had anxiety, and $12 \%$ suffered from stress, which were all higher than in the general population. Alamri et al ${ }^{28}$ also showed that females were more affected than males. In the present study, more than a third of the respondents demonstrated symptoms of anxiety and depression, while more than half of them demonstrated significant features of stress and anxiety. Though not significantly different, females had higher levels of anxiety than males, while males had higher levels of depression, stress, and burnout than females.

There were some limitations to the present study. First, the sample size was relatively small, which needs to be considered in future studies. Second, the study outcomes depended mainly on the responses of the respondents, which relied on their honesty and subjective opinions, which could influence the reliability of the findings. Third, there was only one respondent from the North region, which might have biased the results and the comparisons for the depression estimation among the different regions.

\section{Conclusions}

EM trainee residents in Saudi Arabia have been exposed to significant levels of psychological affectation, on both professional and social levels, during the COVID-19 pandemic. EM training has many aspects that require trainees to be attentive and focused in order to grasp important critical skills.

Although psychological support programs were available, awareness about them proved to be inadequate. Accordingly, through the present findings, we endorse awareness workshops or on-the-job orientation for EM residents about psychological support. Further studies are also required for other medical specialties and different healthcare professionals.

\section{List Of Abbreviations}

COVID-19: coronavirus disease 2019

EM: Emergency Medicine

SCHS: Saudi Commission of Health Specialties

SDS: Self-Rating Depression Scale

\section{Declarations}

\section{Ethics approval and consent to participate}

The study was approved by the Institutional Review Board of the Princess Nourah bint Abdulrahman University (IRB log number: 200269).

\section{Consent for publication}

Not Applicable

\section{Availability of data and materials}

The dataset supporting the conclusions of this article is available upon reasonable request from the corresponding author.

\section{Competing interests}

The authors declare that they have no competing interests.

\section{Funding}

Page $14 / 16$ 
No funding was received.

\section{Authors' contributions}

AK, OK, AAG and AAI conceived the study, designed the study, and obtained research IRB approval; OK, AK, GI, and AM supervised the conduct of the study and data collection. OYK and GA managed the data, including quality control. AAI provided statistical advice on study design and analyzed the data. OK, AM, and MA drafted the manuscript, and all authors contributed substantially to its revision. AK takes responsibility for the paper as a whole.

\section{Acknowledgments}

Not applicable.

\section{References}

1. Galbraith N, Boyda D, McFeeters D, Hassan T. The mental health of doctors during the COVID-19 pandemic. BJPsych Bulletin. 2020; 45(2):93-7.

2. Wilson W, Raj JP, Rao S, Ghiya M, Nedungalaparambil M, Mundra $\mathrm{H}$, et al. Prevalence and predictors of stress, anxiety, and depression among healthcare workers managing COVID-19 pandemic in India: A nationwide observational study. Indian J Psychol Med. 2020;42(4):353-8.

3. Lu W, Wang H, Lin Y, Li L. Psychological status of medical workforce during the COVID-19 pandemic: A cross-sectional study. Psychiatry Res. 2020;288:112936.

4. Shaukat N, Ali DM, Razzak J. Physical and mental health impacts of COVID-19 on healthcare workers: A scoping review. Int J Emerg Med. 2020;13(1):40.

5. Ho CS, Chee CY, Ho RC. Mental health strategies to combat the psychological impact of COVID-19 beyond paranoia and panic. Ann Acad Med Singap. 2020;49(3):155-60.

6. Cao J, Wei J, Zhu H, Duan Y, Geng W, Hong X, et al. A study of basic needs and psychological wellbeing of medical workers in the fever clinic of a tertiary general hospital in Beijing during the COVID-19 outbreak. Psychother Psychosom. 2020;89(4):252-4.

7. Huang J, Liu F, Teng Z, Chen J, Zhao J, Wang X, et al. Care for the psychological status of frontline medical staff fighting against Coronavirus Disease 2019 (COVID-19). Clin infect Dis. 2020;71(12):3268-9.

8. Greenberg N, Docherty M, Gnanapragasam S, Wessely S. Managing mental health challenges faced by healthcare workers during covid-19 pandemic. BMJ. 2020;368:m1211.

9. Azoulay E, De Waele J, Ferrer R, Staudinger T, Borkowska M, Povoa P, et al. Symptoms of burnout in intensive care unit specialists facing the COVID-19 outbreak. Ann Intensive Care. 2020;10(1):110.

10. Vagni M, Maiorano T, Giostra V, Pajardi D. Hardiness, stress and secondary trauma in Italian healthcare and emergency workers during the COVID-19 pandemic. Sustainability. 2020;12:2-16.

11. Carmassi C, Foghi C, Dell'Oste V, Cordone A, Bertelloni CA, Bui E, et al. PTSD symptoms in healthcare workers facing the three coronavirus outbreaks: What can we expect after the COVID-19 pandemic. Psychiatry Res. 2020;292:113312.

12. Gupta S, Kohli K, Padmakumari P, Dixit PK, Prasad AS, Chakravarthy BS, et al. Psychological health among armed forces doctors during COVID-19 pandemic in India. Indian J Psychol Med. 2020;42(4):374-8.

13. Cai H, Tu B, Ma J, Chen L, Fu L, Jiang Y, et al. Psychological impact and coping strategies of frontline medical staff in Hunan between January and March 2020 during the outbreak of Coronavirus Disease 2019 (COVID-19) in Hubei, China. Med Sci Monit. 2020;26:e924171. Published 2020 Apr 15. doi:10.12659/MSM.924171.

Page 15/16 
14. Löwe B, Decker O, Müller S, Brähler E, Schellberg D, Herzog W, et al. Validation and standardization of the Generalized Anxiety Disorder Screener (GAD-7) in the general population. Med Care. 2008;46(3):266-74.

15. Al Aseri ZA, Suriya MO, Hassan HA, Hasan M, Sheikh SA, Tamimi AA, et al. Reliability and validity of the Hospital Anxiety and Depression Scale in an emergency department in Saudi Arabia: A cross-sectional observational study. BMC Emerg Med. 2015;15:28.

16. Jiang JM, Seng EK, Zimmerman ME, Sliwinski M, Kim M, Lipton RB. Evaluation of the reliability, validity, and predictive validity of the subscales of the Perceived Stress Scale in older adults. J Alzheimers Dis. 2017;59(3):987-96.

17. Halbesleben JRB, Demerouti E. The construct validity of an alternative measure of burnout: Investigating the English translation of the Oldenburg Burnout Inventory. Work Stress. 2005;19(3):208-20.

18. Walton M, Murray E, Christian MD. Mental health care for medical staff and affiliated healthcare workers during the COVID-19 pandemic. Eur Heart J Acute Cardiovas Care. 2020;9(3):241-7.

19. Braquehais M, Vargas-Cáceres S, Gómez-Durán E, Nieva G, Valero S, Casas M, et al. The impact of the COVID-19 pandemic on the mental health of healthcare professionals. QJM. 2020;113(9); 613-7.

20. Chatterjee SS, Barikar CM, Mukherjee A. Impact of COVID-19 pandemic on pre-existing mental health problems. Asian J Psychiatr. 2020;51:102071.

21. Kang L, Ma S, Chen M, Yang J, Li R, Yao L, et al. Impact on mental health and perceptions of psychological care among medical and nursing staff in Wuhan during the 2019 novel coronavirus disease outbreak: A cross-sectional study. Brain Behav Immun. 2020;87:11-17.

22. Chung JPY, Yeung WS. Staff mental health self-assessment during the COVID-19 outbreak. East Asian Arch Psychiat. 2020;30(1):34.

23. Li Z, Ge J, Yang M, Feng J, Qiao M, Jiang R, et al. Vicarious traumatization in the general public, members, and non-members of medical teams aiding in COVID-19 control. Brain Behav Immun. 2020;88:916-9.

24. Huang JZ, Han MF, Luo TD, Ren AK, Zhou XP. Mental health survey of medical staff in a tertiary infectious disease hospital for COVID-19. Zhonghua Lao Dong Wei Sheng Zhi Ye BingZa Zhi. 2020;38(3):192-5.

25. Lai J, Ma S, Wang Y, Cai Z, Hu J, Wei N, et al. Factors associated with mental health outcomes among health care workers exposed to Coronavirus Disease 2019. JAMA Netw Open. 2020;3(3):e203976.

26. Pappa S, Ntella V, Giannakas T, Giannakoulis G, Papouysi E, Katsaounou P. Prevalence of depression, anxiety, and insomnia among healthcare workers during the COVID-19 pandemic: A systematic review and meta-analysis. Brain Behav Immun.

2020;88:901-7.

27. Salari N, Hosseinian-Far A, Jalali R, Vaisi-Raygani A, Rasoulpoor S, Mohammadi M, et al. Prevalence of stress, anxiety, depression among the general population during the COVID-19 pandemic: a systematic review and meta-analysis. Global Health. 2020;16(1):57.

28. Alamri HS, Algarni A, Shehata SF, BshaBshe AA, Alshehri NN, ALAsiri AM, et al. Prevalence of Depression, anxiety, and stress among the general population in Saudi Arabia during Covid-19 pandemic. Int J Environ Res Public Health. 2020;17(24):9183. 